Western North American Naturalist 68(3), (C) 2008, pp. 278-290

\title{
STRUCTURAL CLASSES AND AGE STRUCTURE IN 1860 AND 1940 RECONSTRUCTED FIR-PINE STANDS OF EASTERN WASHINGTON
}

\author{
Richard Everett ${ }^{1,3}$, David Baumgartner ${ }^{1}$, Peter Ohlson², and Richard Schellhaas ${ }^{2}$
}

\begin{abstract}
We tested for changes in forest structural classes from 1860 to 1940 in 26 dry Pinus ponderosa-Pseudotsuga menziesii stands of northeastern Washington. In 1860 historical fire regimes and associated forest structure remained mostly intact; aerial photos of national forest lands in eastern Washington were taken 70-80 years later and used as historic reference points in regional resource assessments. We determined changes in stand age, tree density, and number of age cohorts per stand between 1860 and 1940. Also, we evaluated whether stand age-class structure in 1860 was in agreement with fire-scar analysis estimates of the historical fire regime. We developed a forest structure classification based on age cohorts and found that forest structural classes varied significantly $(P<0.001)$ from 1860 to 1940. From 1860 to 1940 , average stand age increased by $26 \%$ and number of age cohorts per stand increased by $18 \%$. Stands in stand initiation structural classes declined from $27 \%$ to $4 \%$; stands in old forest structural classes increased from $23 \%$ to $49 \%$. We suggest the 1940 photo record, previously used to assess historical conditions, may provide a false metric of structural complexity for historical dry fir-pine forests in eastern Washington. Competing interpretations of stand age-class structure in 1860 prevented the conclusive verification of historical fire regimes.
\end{abstract}

Key words: forest structure, age cohorts, fire regime, forest classification, historical reference.

The federally mandated assessment of current and historical forest conditions in the Interior Columbia River Basin Assessment (ICRBA; Thomas and Dombeck 1996) created an urgent need for a workable forest structural classification. O'Hara et al. (1996) developed a "dynamic" forest structural classification for use in the ICRBA based, in part, on canopy strata, and in part on the forest dynamics of stem recruitment and stem exclusion. Using canopy strata to estimate dynamic forest processes is problematic; multiple stand development pathways can lead to the same forest structure (Kessell and Fisher 1981, Keane and Long 1998). Also, implicit in the classification in O'Hara et al. (1996) was the assumption that canopy strata represent age cohorts resulting from previous disturbance (Crookston and Stage 1999). However, tree recruitment (future strata) can occur in the absence of disturbance (Brown and $\mathrm{Wu} 2005$ ), and competitioninduced strata can develop in even-aged stands (Bechtold 2003). Also, seedlings may indicate recent stem recruitment or long-term stem exclusion based on their age; suppressed conifer seedlings $<1 \mathrm{~m}$ in height and close to 100 years old are common (Parker and Peet 1984).
In this study we build upon the O'Hara et al. classification but use age cohorts rather than forest strata in defining structural stages. An age cohort is comprised of trees of sequential age classes that reflect a defined recruitment period. Age cohorts define the age-class structure of a stand as depicted in an age-class frequency histogram. Age cohorts are directly linked to the time sequence of recruitment and stem exclusion. Stem exclusion is characterized by a lack of recruitment but may also have self-thinning tree mortality (Oliver and Larson 1990). Age cohorts and stand age-class structure are hierarchically linked to the forest stand age-class distribution and disturbance regime characteristic of forest landscapes (Wallenius 2002). If a disturbance regime is stable for a sufficient length of time, a characteristic distribution of stand structural classes and ages results (Frelich 2002). In fire-dependent forests, the distribution of stand ages provides a means of deducing the fire history for the landscape (Van Wagner 1978); similarly, the analysis of an age-class frequency histogram indicates the fire history of a stand (White 1985, Arno et al. 1995, Kaufmann et al. 2000).

Fire controlled the dry fir-pine forest density and species composition in the Pacific

\footnotetext{
${ }^{1}$ Natural Resources Sciences Department, Johnson Hall, Washington State University, Pullman, WA 99164-6410.

2Okanogan-Wenatchee National Forest, Wenatchee, WA 98801.

${ }^{3}$ E-mail: everettr001@hawaii.rr.com
} 


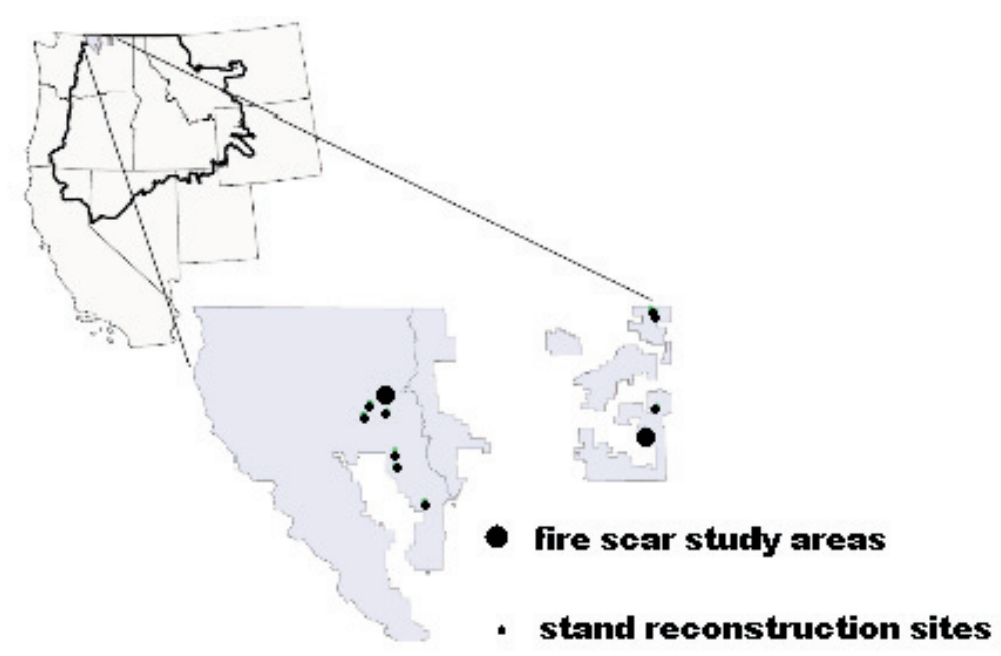

Fig. 1. Study site locations and adjacent fire-scar studies on the Okanogan-Wenatchee National Forest within the Interior Columbia River Basin, USA.

Northwest until the late 1800s, when Eurosettlement activities lengthened fire-return intervals (Arno 1980). Taylor and Skinner (1998), Fulé et al. (1997), and Mast et al. (1999) used 1849,1883 , and 1876, respectively, as the historical "fire" reference period. In our study area, fire-return intervals lengthened after 1860 (Everett et al. 2007); 1860 is the historical reference point for an unaltered fire regime in the forest stands of this study.

Effective fire suppression in the early 1900s allowed understory reinitiation to occur across the Interior West (Covington et al. 1994) and specifically in the Northwest (Weaver 1964, McNeil and Zobel 1980). An unprecedented hybrid forest structure, a sparse overstory created in the presence of fire and a dense understory developing in the absence of fire (Agee 1994), moved forward in time. These altered stand structures would have been recorded in aerial-photo records used by the Eastside Forest Health Assessment (EFHA; Lehmkuhl et al. 1994) and the ICRBA (Hessburg et al. 2000) to estimate historical stand conditions.

In this study we test for differences in types of forest structural classes and their proportions between 1860 (our historical reference) and 1940, a common aerial-photo historical reference period used in ICRBA. Also, we test for differences in stand age and number of age cohorts between 1860 and 1940. Forest structural classes and stand age-class structure in 1860 are evaluated for consistency with the relative roles of low- and mixed-severity fires estimated from a previous fire-scar analysis of the study area. Frequent low-severity fires create small uneven-aged (White 1985) patches in open multimodal-aged stands (Mast et al. 1999). Dense thickets of regeneration interspersed within the open forest matrix indicate torching of individual trees or groups of trees (Cooper 1960, White 1985) or small-stand replacement events (Everett et al. 2000). Schellhaas et al. (2002) estimate that $20 \%$ of the dry fir-pine forest types in watersheds adjacent to our study area are subject to a mixed fire regime.

The following null hypotheses were used in this study: (1) Number of age cohorts per stand, forest structural class types, and structure class representation remained constant between 1860 and 1940. (2) Stand longevity (mean stand age across all sampled stands) remained constant between 1860 and 1940. (3) The 1860 stand ageclass structure reflects that $20 \%$ of stands are reponding to mixed-severity fires and $80 \%$ are responding to low-severity fires, as previously derived from fire-scar analysis.

\section{METHods \\ Study Site}

The data for the 26 stands we used in this study are from 5 Pinus ponderosa-Pseudotsuga menziesii plant association groups on the Okanogan National Forest in northern Washington (Fig. 1). The forest plant association groups are 
warm, mesic shrub-herb forests at low elevations $(600 \mathrm{~m})$ on north slopes; hot, dry shrubgrass forests at $900 \mathrm{~m}$ elevation on southwestfacing slopes; warm, dry tall shrub, and warm, dry shrub-herb forests at $900 \mathrm{~m}$ elevation on northeast and west aspects; and cold, dry grass forests at higher elevations $(1200 \mathrm{~m})$ on all aspects. These plant association groups fall within the following potential vegetation types: Pseudotsuga menziesii with Pinus ponderosa, Pseudotsuga menziesii without Pinus ponderosa, and interior Pinus ponderosa of the Interior Columbia River Basin (Hann et al. 1997). Tree cover on sampled stands ranges from $10 \%$ to $\geq 70 \%$ and is predominantly Pinus ponderosa, Pseudotsuga menziesii, and Larix occidentalis Nutt. (western larch).

Agee's (1994) summary of fire-scar studies for low-elevation pine forests in eastern Washington indicates a historical high-frequency, low-intensity fire regime that transitions to a mixed fire regime with increasing elevation. Everett et al. (2007) estimate the historical composite point mean fire frequency for each of the plant association groups: warm, mesic shrub-herb-7 years; warm, dry shrub-herb16 years; hot, dry shrub-grass-18 years; warm, dry tall shrub-27 years; and cold, dry grass19 years. These estimates are based on 16 fire scars containing 69 fires and a fire record from 1497 to 1898. Results of this limited fire-scar analysis are supported by large fire-scar studies (833 fire scars; Schellhaas et al. 2002, 2003) implemented in watersheds adjacent to our sampled stands (Fig. 1). Schellhaas et al. (2002, 2003) estimate that the Weibull median point fire-frequency interval varies from 11 to 35 years for sites below $1500 \mathrm{~m}$. The majority of forest stands in these watersheds have a highfrequency, low-severity fire regime, but a mixed fire regime occurs on moist sites and at elevations higher than $1500 \mathrm{~m}$, where longer fire frequencies occur. The last recorded fire date in our sampled stands varies from 1866 to 1893 ; 1860 is used as the historical reference point because fire-return intervals lengthen prior to the last fire events in these stands (Everett et al. 2007).

\section{Reconstructed Stands}

Stand reconstruction, for the purposes of this study, involves the determination of establishment dates for live and deadwood stems; we used an existing data set of 26 Pinus pon-
derosa-Pseudotsuga menziesii stands where these establishment dates have been determined (Everett et al. 2007). Establishment dates are used in this study to identify age cohorts, to determine decadal age-class distribution, and to identify periods of recruitment or stem exclusion in each sampled stand. The stand reconstruction methods follow those of previous reconstruction studies (Ohlson 1996, Fulé et al. 1997, Mast et al. 1999) as described in detail in Everett et al. (2007). What follows is a summary of the stand reconstruction methods.

In the initial study we used a completely randomized sampling design that selected stands at random from a mapped population of stands on aerial photographs; the sample population was limited to stands with little or no evidence of timber harvest. Cut stumps represented $\leq 0.1 \%$ of live stems on sampled sites; dead and down, needed for stand reconstruction, were unlikely to have been destroyed by timber harvest operations. We sampled live trees and deadwood on 2 randomly located circular 0.04-ha plots within each stand. All live trees $>30 \mathrm{~cm}$ in height were recorded, and snags and logs (naturally occurring dead and down) $>7.6 \mathrm{~cm}$ base diameter were recorded and identified to species and decay class. Decay classes for snags and logs follow descriptions given by Cline et al. (1980) and Maser et al. (1979), respectively. Small snags and logs (2.5$7.6 \mathrm{~cm}$ base diameter) were tallied (all species combined) by plot.

To determine establishment dates of live trees, we took increment cores at breast height $(1.4 \mathrm{~m})$ from all trees $>5 \mathrm{~cm} \mathrm{dbh}$. We used treering counts on cross-sections cut at ground level for a subsample of smaller trees. Also, a subsample of trees were cored at both stump and breast height to determine early growth rates; time required for tree growth from ground level to breast height was computed (Nigh and Everett 2007). We estimated total tree age as the sum of years from the ground level to breast height plus age at breast height.

Establishment dates of deadwood stems were estimated from the combined age at mortality and the length of the post-mortality decay period. Charred deadwood was scarce $(\leq 0.01 \%$ of deadwood stem), indicating a general absence of dead and down in historic stands. Amounts of deadwood did not dramatically increase in stands until the 1930s-1940s, as a result of competitive self-thinning (Everett 
et al. 2007). Wood decay prevented determination of age at mortality or mortality date (Mast et al. 1999, Stephens et al. 2007). However, we estimated mortality age for deadwood from age-dbh regression analysis of live trees; stand deadwood was derived from the same age cohorts as in the live portion of the stand. Regressions were specific to each tree species, and sometimes to specific stands and plots as required for an acceptable $r^{2}$ (average and median $r^{2}=0.71-0.76$ ). Time since mortality was based on median times for snags and logs to reach specific decay states. Median decay times were specific to tree species and to snags or logs within species, as previously determined from a chronosequence of 26 wildfires (Everett et al. 1999). We used median decay times as the best estimates for decay times of individual deadwood pieces. Fulé et al. (1997) and Mast et al. (1999) found no difference in determining historic trees from current deadwood using $75 \%$ and $50 \%$ of estimated decomposition rates in a sensitivity analysis. We recognized the potential to underestimate total tree density because of the loss of small-diameter deadwood over time, but Fulé et al. (1997) discounted this problem. Fulé et al. (1997) reasoned that the numbers of small-diameter trees were kept low in historical stands by frequent fires, mortality from competitive stress did not occur for several decades following recruitment into historical open stands, and slow decay rates in these dry forests would maintain deadwood into the present time.

\section{Structural Classes}

We used stem recruitment/exclusion, stand age, and number of age cohorts in classifying stands and naming forest structural classes. If a recent age cohort (defined below) was present, the stand was in stem recruitment; otherwise, we categorized the stand as being in stem exclusion. Stand age was determined from the average age of the 5 oldest canopy dominants in the stand at each sampling period: 1860, 1940, and 2000 (Huckaby et al. 2001). We defined stand longevity as the time frame in which the majority of the tree population cycles in the stand; stand longevity reflects the interaction between the longevity of the dominant tree species and the environment (including disturbance) in which the species exist. Stand longevity was computed as the composite mean age of the canopy dominants across all sam- pled stands. We used a stand age $\geq 75 \%$ of estimated stand longevity to separate old from young forest stands. Although there is no specific age when stands take on old-forest characteristics (Hunter and White 1997), the $\geq 75 \%$ rule in our stands approximated the 200-year age that Huckaby et al. (2001) gave for the initiation of old-growth Pinus ponderosa characteristics.

We used $20 \%$ of the stand rotation age (stand longevity) as the recruitment period for the average age cohort after Loewenstein et al. (2000); the $20 \%$ recruitment period was derived from the definition of even-aged stands that should differ in age by no more than $20 \%$ of rotation length (Helms 1998). The $20 \%$ estimate agreed with the average width of recruitment peaks in our data set. We used an estimated age cohort width of 50 years and the bimodal proportion test with $P<0.01$ to determine the number of age cohorts present, as described in detail by Loewenstein et al. (2000). The bimodal proportions test is used in repeated applications to determine whether the age distribution of trees in a stand can be contained in 1, 2, 3, or more "modal age intervals" (age cohorts). Multiple recruitment pulses of 30- to 60-year duration were described for dry pine forests (Mast et al. 1999), and Taylor and Skinner (1998) used a 60-year recruitment period in the analysis of stand structure and fire history in dry Pseudotsuga menziesii stands of northern California. Where the median age of the youngest age cohort was less than or equal to one-half the estimated age cohort width, the stand was considered in stem recruitment, otherwise stem exclusion. For this study, stem recruitment was based on the presence of a cohort with a median age in the 20to 30 -year age class, a time period bracketing the midpoint of a 50 -year age cohort.

\section{Stand Age Structure and Fire Regime}

We examined the age-class structure of historical stands in decadal age-class frequency histograms to estimate the proportion of stands responding to low- or mixed-severity fires. The presence of only 1 or 2 recruitment pulses (Arno et al. 1995) or an age cap (a significant recruitment pulse preceded by none to few old trees) indicated a severe fire event (Kaufmann et al. 2000). As the number of age cohorts per stand increases with fire frequency (Taylor 
TABLE 1. Structural classes based on stem recruitment, stem exclusion, number of age cohorts, and cohort age.

\begin{tabular}{|c|c|c|c|c|}
\hline \multirow[b]{2}{*}{ Process } & \multicolumn{3}{|c|}{$\begin{array}{c}\text { Structural classes } \\
\text { by number of age cohorts }\end{array}$} & \multirow[b]{2}{*}{ Age criteria } \\
\hline & 1 & 2 & $3+$ & \\
\hline stem recruitment ${ }^{1}$ & SIRC & SIRP & & A single recruitment pulse age $<30 \mathrm{yrs}$ \\
\hline stem recruitment & & YFR & YMR & no cohorts $>75 \%$ stand longevity \\
\hline stem recruitment & & OMR & OMR & cohort(s) $>75 \%$ stand longevity \\
\hline stem exclusion $^{2}$ & $\mathrm{MFSE}^{3}$ & & & no cohorts $>75 \%$ stand longevity \\
\hline stem exclusion & ISE & & & no cohorts $>75 \%$ stand longevity \\
\hline stem exclusion & & YMSE & YMSE & no cohorts $>75 \%$ stand longevity \\
\hline stem exclusion & & OMSE & OMSE & cohort $(\mathrm{s})>75 \%$ stand longevity \\
\hline
\end{tabular}

and Skinner 1998), large gaps between age classes may indicate the absence of frequent fires that enable recruitment or loss of trees in those age classes from severe fire events. In this study, stands with age-class histograms of a single age cohort (stands in a stand initiation structural class) and stands $<100$ years old were assumed to be recovering from a mixedto high-severity fire event. Stands $>100$ years old with 3 or more age cohorts (approximating all-age stands) were assumed to be responding to frequent fires. Stands with 2 age cohorts were assumed to be responding to a mixedseverity event if there was a significant gap ( $>50$ years, the average recruitment period) in recruitment between age classes; otherwise, 2 cohort stands are assumed to be responding to low-severity frequent fires. Since multiple explanations for the same age-class structure are possible (Johnson et al. 1994), grouping stands by probable fire regime is only a guide and is subject to further interpretation.

\section{Analysis}

Stand longevity in 1860, 1940, and 2000 was compared in sequential paired $t$ tests (1860 vs. 1940, 1940 vs. 2000; Edwards 1967, JMP 2000). Differences in number of age-class cohorts per stand in 1860 and 1940 were analyzed in a paired $t$ test. The types and representation of structural classes present in 1860 and 1940 were graphically compared, and percent changes in representation were reported. We conducted a chi-square statistical comparison of structural classes present in 1860 and 1940. To ensure adequate cell representation in the chi-square test, we combined the array of structural classes into 3 general groups: stand initiation, young forest, and old forest. The expected representation of stands in these groups (1860) was compared to the observed representation in 1940.

\section{Results}

\section{Revised Structural Classes}

We identified 9 forest structural classes (Table 1). Marginal forest stem exclusion (MFSE) was used as the structural class where there were so few trees on site that no age-class structure was evident; stand initiation recruitment followed complete (SIRC) or partial (SIRP) stand replacement, or represented continuous attempts of tree encroachment onto harsh sites; initial stem exclusion (ISE) followed stand initiation recruitment with or without overstory remnants; young forest recruitment (YFR) occurred as the initial understory recruitment in stands with 2 age cohorts, both aged $<75 \%$ of stand longevity; young multi-aged recruitment (YMR) and young multi-aged stem exclusion (YMSE) classes occurred where stem recruitment or stem exclusion was associated with 3 or more cohorts and all aged $<75 \%$ of stand longevity; old multi-aged recruitment (OMR) occurred in stands with 2 or more cohorts with ages $>75 \%$ of stand longevity; old multistrata stem exclusion (OMSE) occurred where stems were being excluded under multiple-aged cohorts older than $75 \%$ of stand longevity. To reduce classification complexity, we did not subdivide old multi-aged recruitment, young multi-aged stem exclusion, or old multi-strata stem exclusion based on the presence of either 2 or 3 cohorts. However, this could readily be done to achieve other user needs. 


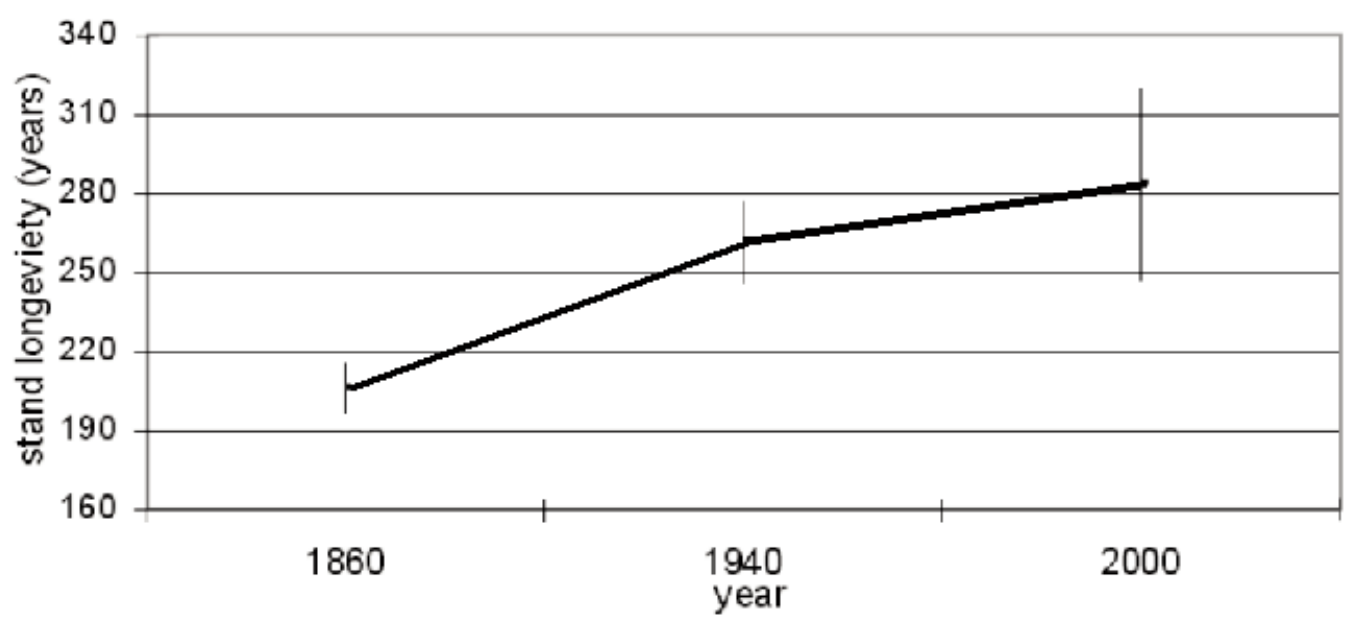

Fig. 2. Stand longevity (average stand age across 26 sites) in 1860, 1940, and 2000. Significant differences in stand longevity are indicated when $95 \%$ confidence bands do not overlap.

\section{Stand Longevity}

In the absence of fire, stand longevity sequentially increased from 1860 to 1940 and from 1940 to 2000 , but the rate of increase declined from 1940 to 2000 as a result of mortality in old trees (Fig. 2). Using $20 \%$ of stand longevity as the average width of an age cohort (Loewenstein et al. 2000) became problematic when stand longevity changed over time. Age cohorts based on $20 \%$ of stand longevity equated to 41,52 , and 56 years in 1860,1940 , and 2000 , respectively. The average width of recruitment peaks in our data set (52 years, $s$ $=15$ ) equaled the $20 \%$ estimate of stand longevity in 1940 and approximated the 50year cohort width previously selected to identify the presence of stem recruitment. Based on these results, we elected to use a 50-year cohort width and a stand longevity estimate of 261 years for both 1860 and 1940 sample periods.

\section{Age Cohorts}

The average numbers of age cohorts per stand significantly $(P<0.05)$ increased by $18 \%$ (2.2 to 2.7 cohorts per stand) from 1860 to 1940. The number of age cohorts increased in 13 of 26 stands. On 8 stands the number of age cohorts remained the same because of old tree mortality, and on 4 stands it remained the same because of minimal recruitment on harsh sites. In 1 stand, mortality in the decadal age classes of trees 150-180 years old was sufficient to reduce the number of age cohorts over the time span from 1860 to 1940.

\section{Historical Forest Structural Classes}

In 1860 approximately $27 \%$ of the stands were in stand initiation recruitment, MFSE, or ISE structural classes (Fig. 3a); stand initiation recruitment may follow partial or complete stand replacement events. Approximately $49 \%$ of the stands were in the young forest classes: YFR, YMR, and YMSE. Approximately $23 \%$ of the stands were in old forest classes: OMR and OMSE (Fig. 3a). These old-forest stands $(>75 \%$ of stand longevity, stand age $>196$ years) were not the result of recent stand-replacement events and did not have long gaps in tree recruitment prior to 1860. Also, representation of shade-intolerant species, Larix occidentalis, or Pinus ponderosa was always $\geq 20 \%$ of tree density and averaged $52 \%(s=25)$ in these historical old-forest stands.

\section{Structural Classes}

In 1940 the only stand initiation class present was initial stem exclusion on a single site representing $4 \%$ of the sampled stands; this stand initiation class was present only as a result of tree encroachment onto the 1860 marginal forest site (Fig. 3a). Young forest representation declined slightly (49\% to $46 \%$ ) from 1860 to 1940 . The representation of stands in old-forest classes increased from $23 \%$ to $49 \%$. Structural classes generally shifted from simpler to more complex age structures from 1860 to 1940. Post-fire understory created stands with 2 age cohorts from stands that previously had 1 age cohort (Figs. 4a, 4b); stands with 2 

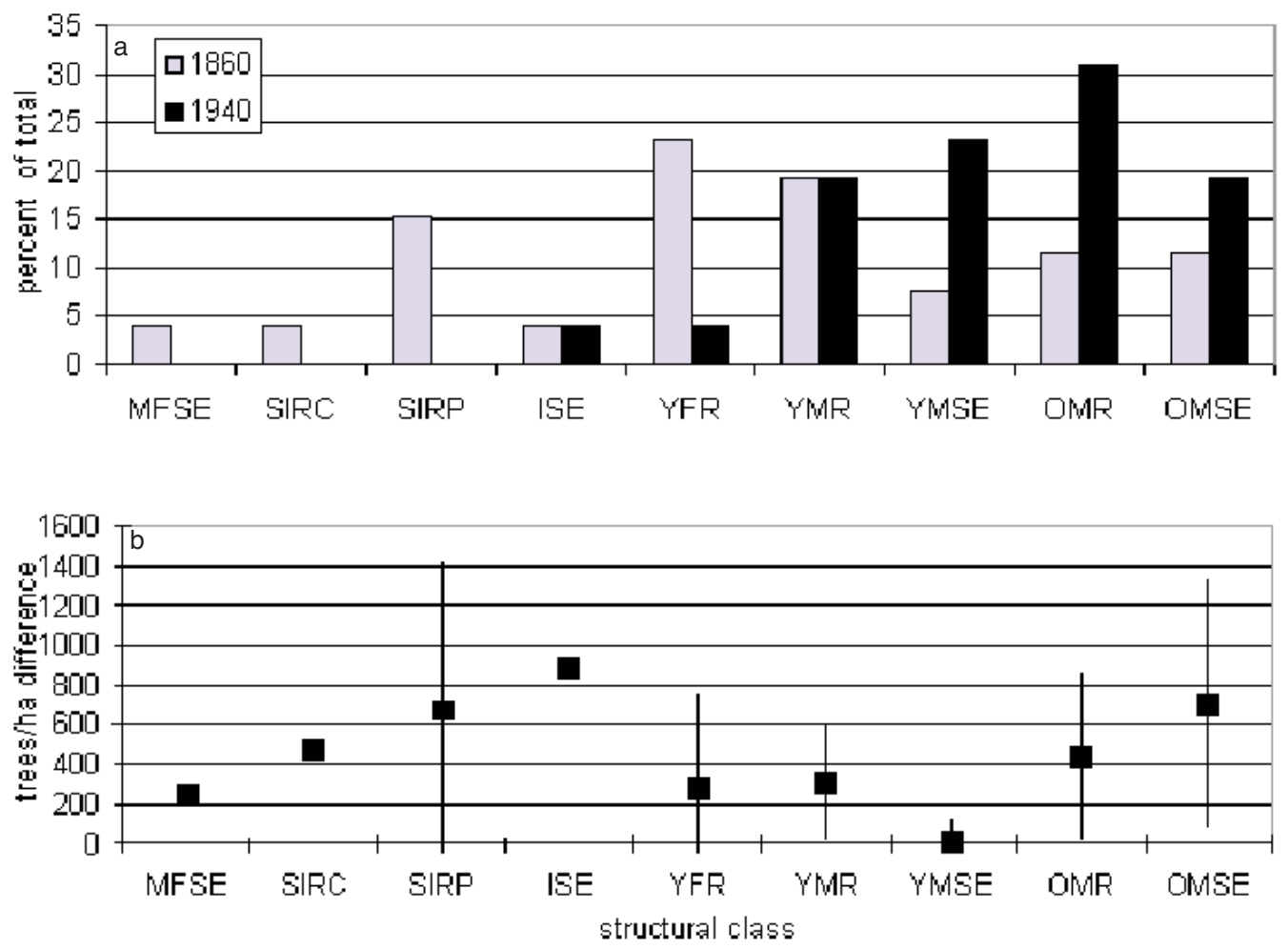

Fig. 3. (a) Structural class representation in 1860 and 1940. MFSE $=$ marginal forest stem exclusion; SIRP, SIRC $=$ stand initiation recruitment following partial or complete stand replacement; ISE = initial stem exclusion; YFR, YMR = young forest in initial or multi-aged understory recruitment; YMSE $=$ young forest stem exclusion; OMR $=$ old forest multi-aged recruitment; OMSE $=$ old forest stem exclusion. (b) Average tree density increase $(\vdots 1 s)$ from 1860 to 1940 by original forest structural class.

age cohorts became stands with 3 or more age cohorts (Fig. 4c). The patch dynamics in old forests caused by the frequent fire-recruitment cycle gave way to a broad recruitment pulse in the absence of fire (Fig. 4d). Mortality of old trees caused a decline in stand age and retrogression in stand development in 1 stand (Fig. 4e). In figure 4 the numbers of trees present in 1860 and in 1940 are shown by their establishment dates: gray columns (1860) without a paired black column (1940) indicate that trees present in 1860 were deadwood by 1940; black columns without paired gray columns indicate recruitment between 1860 and 1940.

Of the 9 structural classes present in 1860 , one-third were absent by 1940 . There was no representation of marginal forest stem exclusion, or stand initiation recruitment (Fig. 3). Without reoccurring fire disturbance, young forest recruitment and young multi-aged recruitment classes progressed to young multi-aged stem exclusion. Stands with 2 or more age classes increased from $73 \%$ to $96 \%$ representation from 1860 to 1940 . The chi-square statistic indicated that representation in stand initiation, young forest, and old forest classes varied significantly $(P<0.001)$ between 1860 and 1940.

\section{Increased Tree Density}

After the cessation of fire, sampled stands had a rapid influx of post-fire recruitment, adding age cohort(s) and increasing stand density. Tree density increased from 1860 to 1940 in all plant association groups and in 24 of 26 sampled stands. Tree densities increased by an average of $150 \%$ from 1860 to 1940 , but the amount of increase was highly variable among structural classes (Fig. 3b). High variability in tree density within all replicated structural classes and the absence of replicates in 3 of the structural classes prevented determination of statistical differences. 

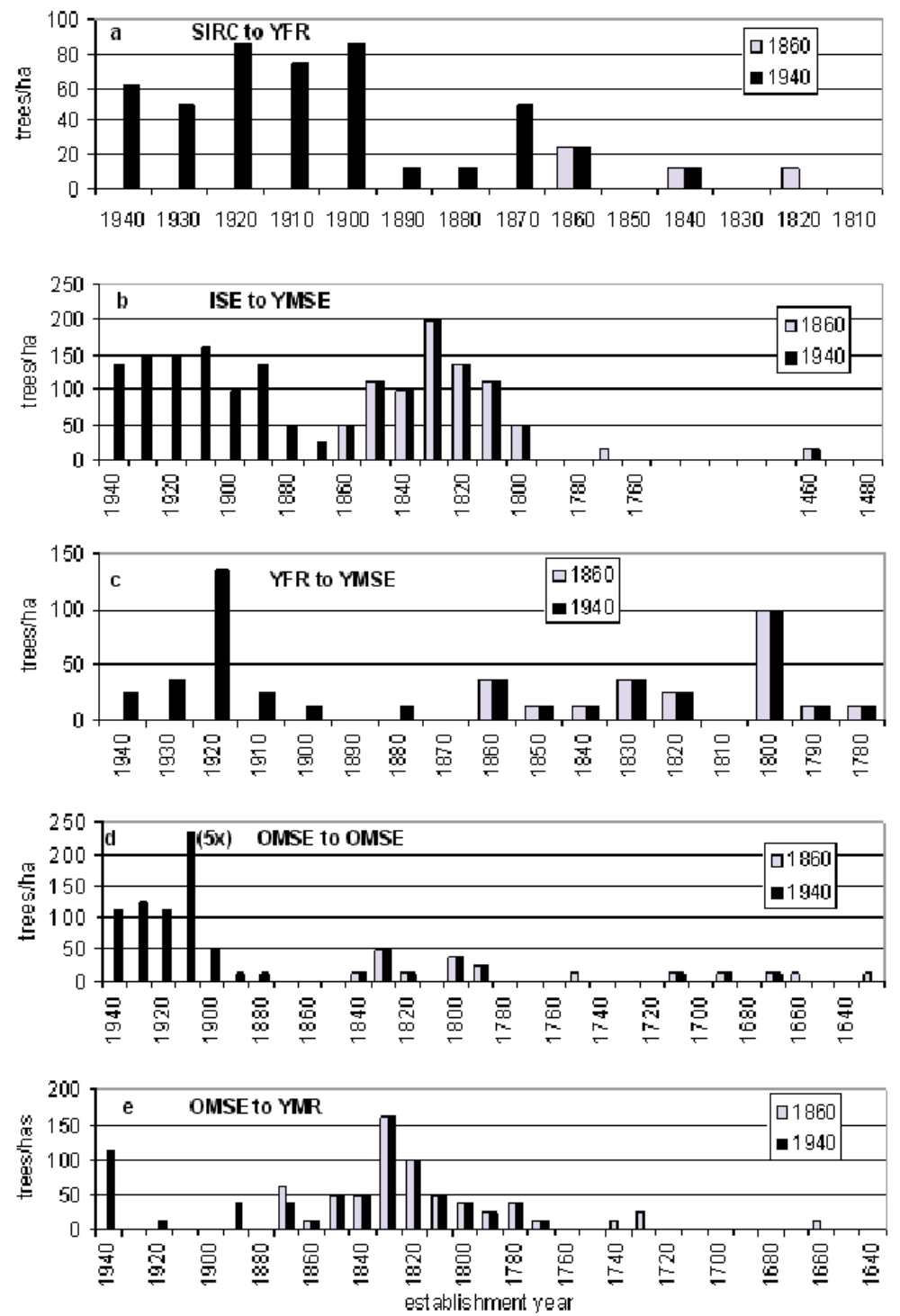

Fig. 4. Number of trees present in 1860 and in 1940 by their establishment date. (a) Transition from 1 age cohort stand initiation recruitment (SIRC) in 1860 to 2 age cohort young forest recruitment (YFR) in 1940. (b) Transition from initial stem exclusion (ISE) in 1860 to young forest multi-aged recruitment (YMSE) in 1940. (c) Transition from young forest recruitment (YFR) in 1860 to young multi-aged stem exclusion (YMSE) in 1940. (d) Post-fire recruitment in an open old multi-aged stem exclusion (OMSE) stand in 1940. (e) Stand development retrogression from old multi-aged recruitment (OMR) in 1860 to young multi-aged recruitment in 1940 as a result of old tree mortality; all trees establishing prior to 1760 were deadwood by 1940 .

\section{Stand Age-class Structure} and Fire Regime

Based on our criteria for interpreting ageclass histograms, stands appeared equally divided between those with age-class histograms characteristic of high-frequency, lowseverity fires and those with age-class his- tograms indicating mixed-severity fire events. The mixed-severity fire group contained 5 stands $<100$ years of age, 3 stands (with older remnants) classified as stand initiation, and 5 older stands with gaps $>70$ years between age classes. Stands grouped in with the high-frequency, low-severity fire regime had an average stand age of 180 years; 9 stands had 3 or 
more age cohorts, and an additional 4 stands had 2 age cohorts per stand with only short gaps ( $<30$ years) between age classes.

\section{Discussion}

\section{Structural Classes}

This study builds upon the previous forest structural classification of O'Hara et al. (1996), but differs in that we used stand age, number of age cohorts, and stem recruitment or stem exclusion in identifying and naming all structural classes. Determining the presence or absence of stem recruitment was a key criterion in determining structural classes in both classification schemes. Identifying stem recruitment based on the median age of a young age cohort was more precise than using a low strata tree layer; we encountered numerous seedlings $(<1 \mathrm{~m})>70$ years of age. The O'Hara et al. (1996) classification assumed a close agreement between strata and age cohorts; but this relationship varies by forest type and method of stratification. The Forest Vegetation Simulator stratification algorithm used to identify strata from aerial photos in the ICRBA (Stage 1997, Crookston and Stage 1999) had poor agreement between number of age cohorts and number of strata in a sample of dry fir-pine forest stands from eastern Washington (Everett et al. 2008).

\section{Change in Forest Structural Classes}

The significant increase in the average number of age cohorts per stand between 1860 and 1940 should translate into increased complexity in canopy forest structure. Although different strata may be of the same age (O'Hara et al. 1996), different age cohorts are likely to create different strata (Everett et al. 2008). Under the assumption that age cohorts reflect different forest strata (Stage 1997, Crookston and Stage 1999), the forest structure defined in 1940 aerial photos should have more strata than the historical forest of 1860. Without the same number of age cohorts (strata) per stand, it would appear difficult for 1860 and 1940 stands to have had the same structural classes or the same representation of classes.

Of the 9 structural classes identified in 1860, only 6 were present in 1940. Structural classes common to both 1860 and 1940 changed in their representation between sampling dates; a significant number of stands transitioned from stand initiation structural classes into young forests, and an almost equal number of young forest stands transitioned into old forest. The trend of declining representation of early stand development classes continued from the period of the early aerial photo dates (1940s) into the 1990s (EFHA; Lehmkuhl et al. 1994).

Fire exclusion and tree recruitment, the causative processes for forest structure change, were common in dry fir-pine forests of the Inland West (Covington et al. 1994), on the east slope of the Washington Cascades (Everett et al. 2000), and in watersheds surrounding the study area (Schellhaas et al. 2002, 2003). Insect outbreaks caused tree mortality in eastern Oregon and southeastern Washington in the late 1800s and early 1900s (Weaver 1943, 1964, Oliver et al. 1994), but insect pests such as Dendroctonus ponderosae Hopkins (mountain pine beetle) were not at serious levels in northeastern Washington forests at that time (Oneil 2006). However, the serious drought of the 1920s-1930s stressed large, old Pinus ponderosa and made them susceptible to attack by Dendroctonus brevicomis LeConte (western pine beetle; Hessburg et al. 1994). Old-tree mortality caused stand development retrogression in 1 stand and caused stand age to decline from 1860 to 1940 in $10 \%$ of the sampled stands.

\section{Stand Longevity}

Stand longevity increased from 206 to 261 years from 1860 to 1940 . In 1860 stand longevity was significantly less than the maximum of 283 years recorded in 2000. White (1985) suggested the flat age distribution in older age classes of Pinus ponderosa was the result of periodic mortality of trees of all age classes caused by fire, insects, or pathogens. We suggest these same processes may have limited the historical stand age and defined the time frame in which tree populations cycled on these sites. In the absence of fire, stand longevity in these dry forests dramatically increased but was then constrained by mortality of old trees that were in competition with an abundant understory (Weaver 1943, 1964, Mast et al. 1999).

\section{Stand Age Structure and Fire Regime}

The previous fire-scar analysis for these stands and adjacent watersheds provided a composite point fire frequency of 7 to 35 years (Schellhaas et al. 2002, 2003, Everett et al. 2007). These fire frequencies are indicative of 
a high-frequency, low-severity fire regime (Agee 1994, Brown 2000) but also indicate the potential for more severe fire events on sites with longer fire frequencies. Approximately $20 \%$ of the dry fir-pine forest type in the adjacent watershed was subject to mixed-severity fires (Schellhaas et al. 2002). Severe fire events, by definition, cause significant tree mortality and destroy the fire record over time. Because of the loss of fire records on severe burn sites, Baker (2006) suggests that the analysis of fire scars is weighted to sites frequently burned at low severity. Fire-scar analysis may overestimate fire frequency and not capture the fire dynamics of the entire landscape. Stand ageclass structure, a less definitive fire metric, may provide insight into stand fire history where fire scars are absent. However, using stand age-class structure to determine the relative roles of low- and mixed-severity fires is problematic; multiple explanations are possible for the same stand age-class structure (Johnson et al. 1994).

Thirteen of the 26 sampled stands were $\geq 150$ years old, had short gaps in recruitment, and had multiple age cohorts with shade-intolerant species (e.g., Figs. 4c, 4d). Cooper (1960, 1961), Morrow (1985), and Arno et al. (1995) linked this stand structure to a high-frequency, low-severity fire regime. The remaining 13 stands had an age-class structure with few old trees, a significant pulse of recruitment (an age gap; Fig. 4b), or large gaps between age classes that could indicate a previous stand replacement event (Arno et al. 1995, Kaufmann et al. 2000).

Large gaps between age classes did not prove to be a useful indicator of severe fire events in this study. Although frequent fires provide opportunities for recruitment (Taylor and Skinner 1998), large gaps in recruitment (and age classes) can occur under a frequent fire regime (Cooper 1960, White 1985, Arno et al. 1995). Even if large gaps between age classes indicate loss of trees in a severe fire event, the fire would have occurred 130 to 150 years prior to 1860 in 5 of the sampled stands (e.g., Fig. 4e; 130-year gap). In 1860 stand density on these 5 stands was low (approximately onethird of 1940 levels) and was apparently being maintained at these low levels by frequent fires.

Also, ascribing all young stands to recent stand-replacement fires may not be justified. Previous forested stands removed by fire can be maintained as forest openings for over a century (Kaufmann et al. 2000). Four stands in the hot, dry shrub-grass plant association group in 1860 had stand ages from 50 to 100 years and mean/median tree densities averaging $83 / 82$ trees $\cdot \mathrm{ha}^{-1}\left(1\right.$ tree per $\left.120 \mathrm{~m}^{2}\right)$. On harsh sites where tree densities remain low over time and crown fuel levels are low and dispersed, a severe crown-fire stand-replacement event appears unlikely. We suggest, in these 4 stands, that frequent surface fires are the more probable cause for a loss of all trees or the maintenance of a young age cap by the sequential torching of individual trees (Scott and Reinhardt 2001). Complete tree removal by 1 severe fire or by frequent surface fires could provide the same stand age-class structure (e.g., Fig. 4a). The presence of large, charred dead and down stems would suggest stand-replacement events, but charred deadwood was scarce in all our sampled stands. Dead and down stems are frequently absent from Pinus jeffreyi Grev. and Balf mixedconifer stands in Mexico if the frequent fire regime remains intact (Stephens et al. 2007).

A frequent fire regime appears more plausible for 9 of 13 stands initially thought to indicate severe fire events. Only 4 stands, all in stand initiation structural stages (16\% of the total number of stands), appeared to be recovering from a recent mixed to severe fire event in 1860 . These results are in agreement with Ehle and Baker (2003), who reported that highseverity and mixed-severity fires made up only a portion (10\% and 3\%, respectively) of the identified fire events in an otherwise predominantly low-severity fire regime. Results also approximate the fire-scar analysis of Schellhaas et al. (2002) that indicated that $20 \%$ of the dry forest type in an adjacent watershed had a mixed fire regime.

Our results conflict with aerial-photo interpretations that suggest that the last fire event in $77 \%$ of dry forest stands in the Interior Columbia River Basin was either high or mixed severity (Hessburg et al. 2004). In Hessburg et al. (2004), stands where overstory contributed $<30 \%$ of the total tree cover were considered the result of mixed to severe fire events. Severe fire events may have occurred in the history of these stands, creating copious amounts of deadwood, but the last fire event in many of these stands was more likely a frequent, low-severity fire that consumed the 
current "missing" deadwood (Thomas and Agee 1986). We suggest that $<30 \%$ overstory cover in an aerial photo may reflect a process other than a response to a severe fire event. In our study we found that age-class histograms with few old trees and a wide recruitment pulse (e.g., Fig. 4d) could readily be interpreted as either (1) recruitment following a partial stand-replacement event or (2) recruitment resulting from a gap in frequent fires in an open stand. Historically, significant recruitment occurred between frequent fire events (Ohlson 1996), and gaps in fire frequency allowed pulses of understory to create at least a transient dense understory (Everett et al. 2000). We suggest the 2 scenarios could produce stands with $<30 \%$ overstory cover in 1940 aerial photos after 80 years of post-fire understory tree growth. If in the aerial photo analysis the results of both scenarios were ascribed to just severe fire events and resulting recruitment, the estimated roles of mixedseverity fires and the estimated proportions of stand initiation structural stages would be inflated.

\section{Conclusions}

We present a forest structural classification based on age cohorts with a consistent nomenclature among classes. Using this classification, we reject the null hypothesis that forest structural class types and structural class representation remained constant over the time span between 1860 and 1940. The types of structural classes and their representation varied significantly from when fire regimes were mostly intact in 1860 to when the 1940 historical aerial photo record was taken. Forest structural classes and their proportions on the landscape, as determined in 1940 aerial photos, may not be representative of historical conditions. The use of these photo records as historical reference states in large-scale forest assessments (EFHA and ICRBA - in which the authors participated) was expedient, but derived results require review.

We reject the null hypothesis that stand longevity remained constant between 1860 and 1940. Stand longevity increased from 1860 to 1940 in the absence of fire, but the rate of increase subsequently declined with mortality of old trees in competition with a ubiquitous post-fire understory.
Competing interpretations of 1860 stand age-class frequency histograms prevent us from either accepting or rejecting the null hypothesis that 1860 stand age-class structure reflects that $20 \%$ of stands respond to mixed-severity fires and $80 \%$ respond to low-severity fires, as previously derived from fire-scar analysis. Although our interpretation of age-class structure (histograms) suggests approximately $84 \%$ of the 1860 stands are responding to frequent fires, the age-class structure of 9 stands (34\% of the total) is not definitive and is subject to multiple interpretations.

Baker (2006) found fire-scar analysis to be weighted to those sites that burn frequently; we found the use of age caps in age-class histograms to overestimate the role of severe fire events. Age caps may indicate severe fire events or other forest processes. A gap in frequent fires and a recruitment pulse in an open historical stand create an age cap without a severe fire event. We find the analysis of fire scars and the analysis of age-class histograms are not conclusive as to the relative roles of low- to high-severity fire events; however, both analyses indicate a mixed fire regime for the sampled landscape.

\section{Literature Cited}

AgEe, J. 1994. Fire and weather disturbance in terrestrial ecosystems of the eastern Cascades. USDA Forest Service, General Technical Report PNW-GTR-320, Portland, OR. 52 pp.

ARNo, S. 1980. Forest fire history in the Northern Rockies. Journal of Forestry 78:460-465.

Arno, S., J. Scott, and M. Hartwell. 1995. Age-class structure of old growth ponderosa pine / Douglas-fir stands and its relationship to fire history. USDA Forest Service, Research Paper INT-RP-481, Ogden, UT. $25 \mathrm{pp}$.

BAKER, W. 2006. Fire history in ponderosa pine landscapes of Grand Canyon National Park: is it reliable enough for management and restoration. International Journal of Wildland Fire 15:433-437.

BEChtoLD, W. 2003. Crown position and light exposure classification-an alternative to field-assigned crown class. Northern Journal of Applied Forestry 20:154160.

BRown, J. 2000. Introduction and fire regimes. Pages 1-7 in J. Brown, K. Smith, and J. Kapler, editors, Wildland fire ecosystems: effect of fire on flora. USDA Forest Service, Rocky Mountain Research Station. General Technical Report RMRS-GTR-42-Vol. 2, Fort Collins, CO.

BRown, P., AND R. WU. 2005. Climate and disturbance forcing of episodic tree recruitment in a southwestern ponderosa pine landscape. Ecology 86:3030-3038. 
Cline, S., A. Berg, and H. Wight. 1980. Snag characteristics and dynamics in Douglas-fir forests, western Oregon. Journal of Wildlife Management 44:773-786.

Cooper, C. 1960. Changes in vegetation, structure and growth of southwestern pine forests since white settlement. Ecological Monographs 30:129-164.

1961. Pattern in ponderosa pine forests. Ecology 42:493-499.

Covington, W., R. Everett, R. Steele, L. Irwin, T. Daer, AND A. AuClair. 1994. Historical and anticipated changes in forest ecosystems of the Inland West of the United States. Journal of Sustainable Forestry 2:13-64.

Crookston, N., and A. Stage. 1999. Percent canopy cover and stand structure statistics from the forest vegetation simulator. USDA Forest Service, Intermountain Research Station, General Technical Report RMRSGTR-24, Ogden, UT. 9 pp.

EDWARDS, A. 1967. Statistical methods. 2nd edition. Holt, Rinehart and Winston, Inc., New York. 462 pp.

Ehle, D., and W. BaKer. 2003. Disturbance and stand dynamics in ponderosa pine forests in Rocky Mountain National Park, USA. Ecological Monographs 73: 543-566.

Everett, R., D. Baumgartner, P. Ohlson, and R. SchelLHAAS. 2008. Defining and quantifying canopy strata. Northwest Science 82:48-64.

Everett, R., D. Baumgartner, P. Ohlson, R. Schellhaas, AND R. HaRRoD. 2007. Development of current stand structure in dry fir-pine forests of northern Washington. Journal of the Torrey Botanical Society 134: 199-214.

Everett, R., J. Lehmkuhl, R. Schellhats, P. Ohlson, D., Keenum, H. Riesterer, and D. Spurbeck. 1999. Snag dynamics in a chronosequence of 26 wildfires on the east slope of the Cascade Range in Washington State, USA. International Journal of Wildland Fire 9:223-234.

Everett, R., R. Schellhaas, D. Keenum, D. Spurbeck, AND P. OHLson. 2000. Fire history in the ponderosa pine / Douglas-fir forest on the east slope of the Washington Cascades. Forest Ecology and Management 129:207-225.

Frelich, L. 2002. Forest dynamics and disturbance regimes. Cambridge University Press, London. 276 pp.

Fulé, P., W. Covington, And M. Moore. 1997. Determining reference conditions for ecosystem management of southwestern ponderosa pine forests. Ecological Applications 7:895-908.

Hann, W., J. Jones, M. Karl, P. Hessburg, R. Keane, D. LONG, J. Menakas, C. MCNicoll, ET AL. 1997. Landscape dynamics of the basin. Pages 337-1055 in T. Quigley and S. Arbelbide, editors, Volume 2. An assessment of ecosystem components in the interior Columbia River Basin and portions of the Klamath and Great Basin. USDA Forest Service, General Technical Report PNW-GTR-405, Portland, OR.

Helms, J., EDITOR. 1998. The dictionary of forestry. Society of American Foresters, Bethesda, MD.

Hessburg, P., R. Mitchell, and G. Filip. 1994. Historical and current roles of insects and pathogens in eastern Oregon and Washington forested landscapes. USDA Forest Service, Pacific Northwest Research Station, General Technical Report PNW-GTR-327, Portland, OR. 72 pp.
Hessburg, P., R. Salter, and K. James. 2004. Evidence for mixed severity fires in pre-management era dry forests of the Inland Northwest, USA. Pages 89-104 in L. Taylor, J. Zelnik, S. Cadwallader and B. Hughes, compilers and editors, Mixed severity fire regimes: ecology and management. Assoc. Fire Ecol. AFE MISCO3. Washington State University, Pullman.

Hessburg, P., B. Smith, R. Salter, R. Ottmar, and E. ALVARADO. 2000. Recent changes (1930's-1990's) in spatial patterns of Interior Northwest forests, USA. Forest Ecology and Management 136:53-83.

Huckaby, L., M. Kaufmann, J. Stoker, and P. Fornwalt. 2001. Landscape patterns of montane forest age structure relative to fire history at Cheesman Lake in the Colorado Front Range. Pages 19-27 in R. Vance, C. Edminster, W. Covington, and J. Blake, compilers, Ponderosa pine ecosystems restoration and conservation: steps toward stewardship. USDA Forest Service, Proceedings RMRS-P-22, Fort Collins, $\mathrm{CO}$.

Hunter, M., AND A. White. 1997. Ecological thresholds and the definition of old-growth forest stands. Natural Areas Journal 17:292-296.

Johnson, E., K. Miyaniski, and H. KLEb. 1994. The hazards of interpretation of static age structures as shown by stand reconstructions in a Pinus contorta-Picea engelmannii forest. Journal of Ecology 82:923-931.

JMP. 2000. Statistics and graphics guide. Version 4. SAS Institute Inc., Cary, NC.

Kaufmann, M., C. Regan, and P. Brown. 2000. Heterogeneity in ponderosa pine / Douglas-fir forests: age and size structure in unlogged and logged landscapes of central Colorado. Canadian Journal of Forest Research 30:698-711.

Keane, R., and D. LONG. 1998. A comparison of coarse scale fire effects simulation strategies. Northwest Science 72:79-90.

Kessell, S., And W. Fisher. 1981. Predicting post fire plant succession for fire management planning. USDA Forest Service, Intermountain Research Station, General Technical Report INT-94, Ogden, UT. $19 \mathrm{pp}$.

Lehmkuhl, J., P. Hessburg, R. Everett, M. Huff, and R. Otтмar. 1994. Historical and current forest landscapes of eastern Oregon and Washington. USDA Forest Service, Pacific Northwest Research Station, General Technical Report PNW-GTR-328, Portland, OR. 88 pp.

Loewenstein, E., P. Johnson, and H. Garkett. 2000. Age and diameter structure of a managed uneven-aged oak forest. Canadian Journal of Forest Research 30: 1060-1070.

Maser, C., R. Anderson, K. Cromack, J. Williams, and R. Martin. 1979. Dead and down woody material. Pages 78-95 in J. Thomas, editor, Wildlife habitats in managed forest, the Blue Mountains of Oregon and Washington. USDA Forest Service, Agriculture Handbook No. 553, Washington, DC.

Mast, J., P. Fulé, M. Moore, W. Covington, and A. WALTZ. 1999. Restoration of presettlement age structure of an Arizona ponderosa pine forest. Ecological Applications 9:228-239.

MCNEIL, R., AND D. ZobeL. 1980. Vegetation and fire history of a ponderosa pine-white fir forest in Crater Lake National Park. Northwest Science 54:30-46. 
Morrow, R. 1985. Age structure and spatial pattern of oldgrowth ponderosa pine in Pringle Falls Experimental Forest, central Oregon. Master's thesis, Oregon State University, Corvallis. $80 \mathrm{pp}$.

Nigh, G., AND R. EveretT. 2007. Years-to-stump-height and years-to-breast-height models for interior Douglas-fir, western larch and ponderosa pine. Northwest Science 81:293-304.

O’Hara, K., P. Lathram, P. Hessburg, and B. Smith, 1996. A structural classification for Inland Northwest vegetation. Western Journal of Applied Forestry 11: 97-102.

Ohlson, T. 1996. Fire regimes of the ponderosa pineDouglas-fir / beardless bluebunch wheatgrass plant association in the Methow Valley of north central Washington. Master's thesis, Washington State University, Pullman. $87 \mathrm{pp}$.

Oliver, C., L. Irwin, AND W. Knapp. 1994. Eastside forest management practices: historical overview, extent of the application, and their effects on sustainability of ecosystems. USDA Forest Service, Pacific Northwest Research Station, General Technical Report PNWGTR-324, Portland, OR. 70 pp.

Oliver, C., AND B. LARSON. 1990. Forest stand dynamics. McGraw Hill, New York. 467 pp.

OneIL, E. 2006. Developing stand density threshold to address mountain pine beetle susceptibility in eastern Washington forests. Doctoral dissertation, University of Washington, Seattle. $98 \mathrm{pp}$.

Parker, A., and R. PeEt. 1984. Size and age structure of conifer forest. Ecology 65:1685-1689.

Schellhaas, R., D. Spurbeck, P. Ohlson, D. Keenum, AND A. Conway. 2002. Report to the Okanogan and Wenatchee National Forests on the results of the Frosty Creek Planning Area fire history research. USDA Forest Service, Wenatchee Forest Science Laboratory, Wenatchee, WA. 79 pp.

2003 Report to the Okanogan and Wenatchee National Forests on the results of the Twentymile Planning Area fire history research. USDA Forest Service, Wenatchee Forest Science Laboratory, Wenatchee, WA. 67 pp.

SCOTt, J., AND E. ReinhaRdT. 2001. Assessing crown fire potential by linking models of surface and crown fire behavior. USDA Forest Service, Rocky Mountain Research Station, Research Paper RMRS-RP29, Fort Collins, CO. 59 pp.

Stage, A. 1997. Using FVS to provide structural class attributes to a forest succession model (CRBSUM). Pages 139-147 in R. Teck, M. Moeur, and J. Adams, compilers, Proceedings-Forest Vegetation Simulator Conference. USDA Forest Service, Intermountain Research Station, General Technical Report INT-GTR-373, Ogden, UT.

Stephens, S., D. Fry, E. Franco-Vizcaino, B. Collins, AND J. MoghadDas. 2007. Coarse woody debris and canopy cover in an old-growth Jeffrey pine-mixed conifer forest from the Sierra San Pedro Martir, Mexico. Forest Ecology and Management 240:87-95.

Taylor, A., AND C. Skinner. 1998. Fire history and landscape dynamics in a late-successional reserve, Klamath Mountains, California, USA. Forest Ecology and Management 111:285-301.

Thomas, J., AND M. Dombeck. 1996. Ecosystem management in the Interior Columbia River Basin. Wildlife Society Bulletin 24:180-186.

Thomas, T., AND J. AgEe. 1986. Prescribed fire effects on mixed conifer forest structure at Crater Lake, Oregon. Canadian Journal of Forest Research 16:1082-1087.

VAN WAGNer, C. 1978. Age-class distribution and the forest fire cycle. Canadian Journal of Forest Research 8: $220-227$.

WALLENIUS, T. 2002. Forest age distribution and traces of past fires in a natural boreal landscape dominated by Picea abies. Silva Hennica 36:201-211.

Weaver, H. 1943. Fire as an ecological and silvicultural factor in the ponderosa pine region of the Pacific Slope. Journal of Forestry 41:7-14.

1964. Fire and management problems in ponderosa pine. Proceedings of the Annual Tall Timbers Fire Ecology Conference 3:60-79.

White, A. 1985. Presettlement regeneration patterns in a southwestern ponderosa pine stand. Ecology 66:589594

Received 8 May 2007

Accepted 6 February 2008 